\title{
Mortalité par suicide en Suisse romande de 1970 à 1979
}

\section{Pierre-André Etienne}

Institut universitaire de médecine sociale et préventive

17, rue du Bugnon, CHUV, 1011 Lausanne

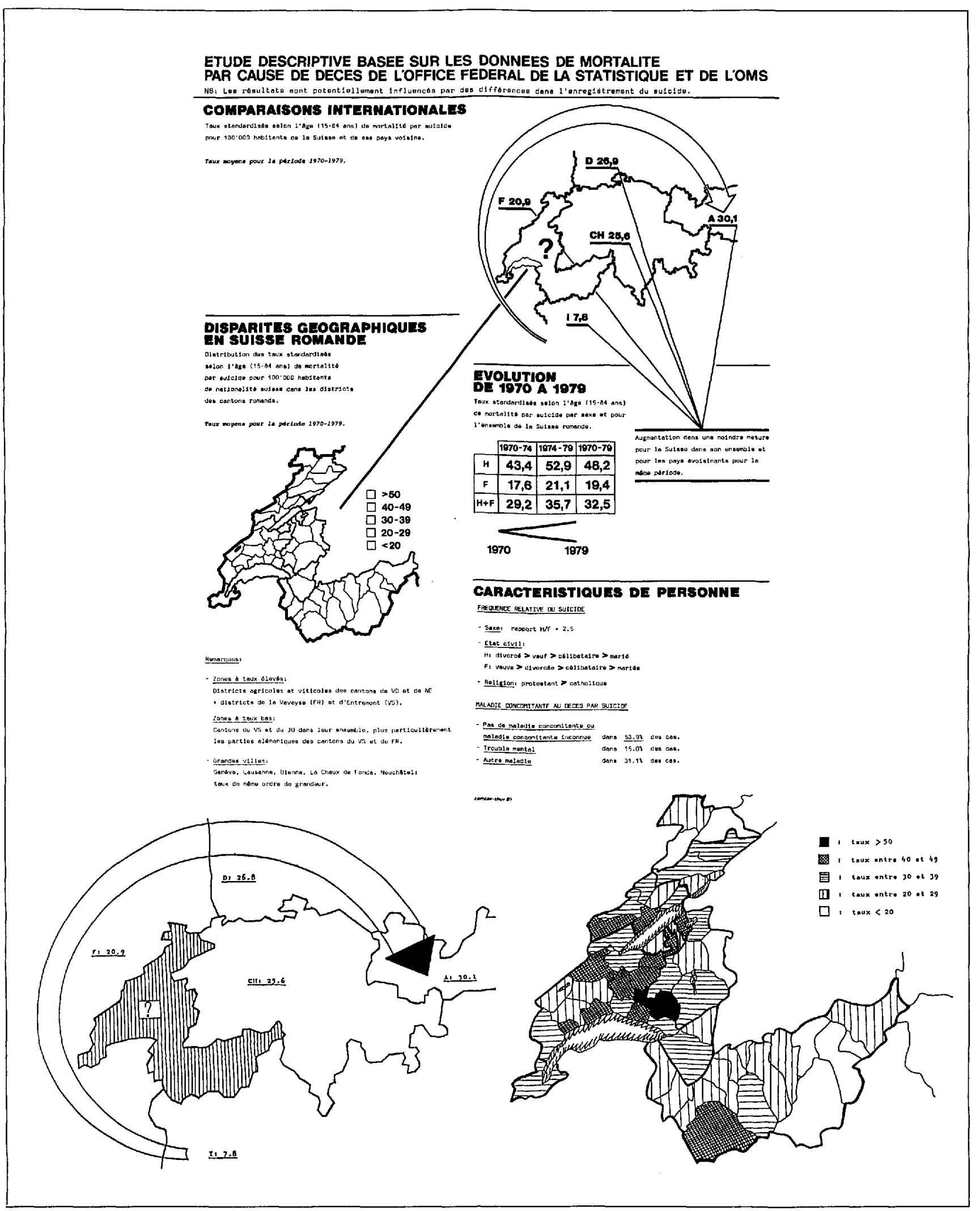

